\title{
INSTITUTIONAL ISOMORPHISM AND CORPORATE SOCIAL RESPONSIBILITY: TOWARDS A CONCEPTUAL MODEL
}

\author{
Maria Roszkowska-Menkes ${ }^{a}$, Maria Aluchna ${ }^{b}$ \\ ${ }^{\mathrm{a}, \mathrm{b}}$ Warsaw School of Economics \\ Management Theory Department, Warsaw, Poland \\ ${ }^{a}$ e-mail: maria.roszkowska-menkes@sgh.waw.pl \\ be-mail: maria.aluchna@sgh.waw.pl
}

\begin{abstract}
Purpose: The paper proposes the conceptual framework for understanding the impact of corporate social responsibility (CSR) on companies viewed as the source of institutional pressure. According to the neo-institutional approach the response to institutional change leads to the organizational isomorphism, which means that companies adopt new rules and design and in result become similar following the same managerial practice. The adoption of new designs and practice represents the case of the diffusion and institutionalization of change in formal organization structure.
\end{abstract}

Methodology/approach: The study is of theoretical character. It adopts the contribution proposed by the neo-institutional theory and CSR literature.

Findings: The paper ties diffusion process of different CSR modes - defensive, charitable, promotional, strategic, systemic - and strategies with three isomorphism mechanisms - mimetic, coercive and normative. Further the study outlines future research opportunities.

Practical implications: We argue that the most mature CSR practice represented by systemic mode is institutionalized from within organization through normative isomorphic pressures rather than as a result of coercive power or mimetic efforts.

Keywords: corporate social responsibility, institutional theory, isomorphism

Paper type: Conceptual paper

\section{Introduction}

Corporate social responsibility (CSR) agenda is becoming more popular both in public discourse and in management practice. It is hard to find corporate website that would not inform about firm's programs focused on social and environmental issues. The topics of ethics and sustainability have been introduced to managerial education curriculum of most of the universities. Governments and international organizations are working on regulations that would promote responsible business 
INSTITUTIONAL ISOMORPHISM

Maria Roszkowska-Menkes

Maria Aluchna practices, while NGOs and consulting companies are developing standards to help companies in the sustainability transition process.

CSR is also one of the most intensively researched topics in management literature. Driven by the growing importance to stakeholders and the failures of value based management corporate social responsibility offers a new business philosophy, shifting the focus from financial performance and shareholder primacy towards social and environmental performance and shared value maximization (Porter and Kramer, 2011). Adopting CSR means incorporating certain changes to company strategy and operation, reporting and procedures. In the language of institutional theory it represents the implementation of new practice and organizational change. The set of new rules and norms has to be translated into company strategy, needs to take the form of decision making patterns and must assure adequate organizational resources for the effective implementation. In doing so organizations can react differently to such changes and pressures and adopt various approaches to respond to them.

The paper is of theoretical character. It proposes the conceptual framework for understanding the impact of corporate social responsibility on companies viewed as the source of institutional pressure. The paper is organized as follows. The new practice provided by CSR implemented at the company level combined with the review of CSR modes are discussed in section one. Section two outlines the neoinstitutional theory, which explains the patterns of organizational response to the institutional change. Adopting the contribution of the neo-institutional theory the section outlines the organizational reaction to institutional change identifying three mechanisms of organizational isomorphism and distinguishing between efficiency seeking and legitimacy strategies. Section three proposes different patterns of isomorphic diffusion of CSR institutional change. Final remarks are presented in conclusion section.

\section{Corporate social responsibility}

CSR is viewed as a concept whereby companies voluntarily integrate social, ethical and environmental concerns into their business operations and core strategy in close cooperation with their stakeholders, with the aim of: maximizing the creation of shared value for their owners/shareholders and for their other stakeholders and society at large; - identifying, preventing and mitigating their possible adverse impacts (COM, 2011). Dahlsrud (2008) identifies five dimensions of CSR: (1) economic, (2) social, (3) environmental - as three dimensions describing types of impacts that businesses have on their environmental - (4) voluntariness that suggests that actions prescribed by law as the minimum socially acceptable level of responsibility, and (5) stakeholders, whose interests define optimal level of responsibility. 
The theoretical perspective of the CSR concept has been developing for six decades and is embedded in a number of concepts (Aluchna, 2015). In the late 1970s Carroll (1979) proposed one of the first and most cited CSR typologies encompassing firm's economic responsibility to investors and consumers, legal responsibility to the government or the law, ethical responsibilities to society and discretionary (philanthropic) responsibility to the community. The author's fourpart definition of CSR was embedded in a conceptual model of corporate social performance (CSP) that incorporated the interaction between the categories of social responsibility, the social issues and the philosophy of social responsiveness (Carroll, 1979; Wartick and Cochran, 1985; Wood, 1991).

Later the opposition towards value based management and the emphasis on corporate responsibilities towards society were pointed out by Donaldson in his seminal book, 'Corporations and Morality' (1982) followed by the proposition of the stakeholder theory by Freeman (Freeman and Reed, 1983). As companies are constellation of cooperative and competitive interests possessing intrinsic value (Donaldson and Preston, 1995), the stakeholder theory assumes that the managers must formulate and implement strategies which satisfy all and only those groups who have a stake in the company's operations (Freeman and McVea, 2001).

Further development of the CSR concept called for the incorporation of CSR into strategic management (Charan and Freeman, 1980). This was supported by the contribution of Prakash Sethi and his elaboration of the measure of social performance tied to financial indicators (Sethi, 1975). Stakeholders are given the crucial role in the process of the corporate decision-making, which identifies them as owners of fiduciaries rights enriching the previous approach emphasizing the stakes and rights controlled by shareholders (Martin, 2002). The distinction between CSR and business goals is viewed as a false dichotomy (Porter and Kramer, 2002) and companies are encourage to integrate social, environmental and economic aspects.

Visser (2012) argues that corporate responsibilities evolves in five overlapping ages (see Table 1), each with one dominant CSR modes:

1) Age of greed and defensive CSR in which all social and environmental initiatives are aimed at keeping civil pressure down and are undertaken only if and when it can be shown that shareholder value will be protected as a result. CSR ad hoc interventions are seen to fend off regulation or avoid fines and penalties.

2) Age of philanthropy and charitable CSR that is when company's responsible practices are limited to support of various social and environmental causes through donations and sponsorships.

3) Age of marketing and promotional CSR viewed as a branding and focused merely on reputational benefits.
INSTITUTIONAL ISOMORPHISM

Maria Roszkowska-Menkes Maria Aluchna 
INSTITUTIONAL ISOMORPHISM

Maria Roszkowska-Menkes Maria Aluchna

Table 1.

The Ages and Stages of CSR

Source: Visser (2012).
4) Age of management and strategic CSR, in which social and environmental activities are related to the company's core business through adherence to CSR codes and implementation of adequate management systems with policy development, goal setting, implementation, auditing and reporting. Strategic CSR is based on the win-win assumption. It focuses on incremental improvements related social and environmental issues that are aligned with business strategy, but does not enforce any radical changes in this strategy.

5) Age of responsibility and systemic CSR that focuses its activities on identifying and tackling the root causes of company's present unsustainability and irresponsibility, typically through innovating business models, revolutionizing processes, products and services and lobbying for progressive national and international policies.

Visser (2012) argues that companies tend to move through different ages and stages of CSR, although they may have activities in several modes at once.

\begin{tabular}{lllll}
\hline Business Age & CSR mode & Modus Operandi & Key Enables & Stakeholder Target \\
\hline Greed & Defensive & $\begin{array}{l}\text { Ad hoc } \\
\text { interventions }\end{array}$ & Investments & $\begin{array}{l}\text { Shareholders, } \\
\text { government and } \\
\text { employees }\end{array}$ \\
\hline Philanthropy & Charitable & $\begin{array}{l}\text { Community } \\
\text { programs }\end{array}$ & Projects & Communities \\
\hline Marketing & Promotional & Public relations & Media & General public \\
\hline Management & Strategic & $\begin{array}{l}\text { Management } \\
\text { systems }\end{array}$ & Codes & Shareholders, NGOs \\
\hline Responsibility & Systemic & Business models & Products & $\begin{array}{l}\text { Regulators and } \\
\text { customers }\end{array}$ \\
\hline
\end{tabular}

Existing studies indicate that despite the underlying assumption of the voluntariness of CSR on the operational level it is well developed both with respect to institutional guidelines and requirements as well as corporate practice. This institutionalization is understood as norms and guidelines for different policies and procedures such as assuring respect for human rights, anti-corruption, antidiscrimination, product and work safety, environmental protection. Additionally, institutionalization is provided by internationally recognized standards for reporting (GRI, IIRC). However, with a number of shortcomings, such as lack of universally accepted definition, principles and scope (Marrewijk, 2003; McWilliams et al., 2006) and abuses related mostly to companies' hiporcrisy accompanying CSR activities (Faust, 2006; Fleming and Jones, 2013; Mullerat, 2010) the question of the firms' motivation for adoption of CSR and the authentic integration of the concept into their strategies remains open. 
3. Institutional isomorphism

Institutions are the systems of rules, beliefs, norms and organizations (Greif, 2006) that impose constrains on human behavior defining what is acceptable and unacceptable, as well as support activities of particular actors providing guidelines and resources for acting. They encompass regulative, normative and cultural-cognitive elements (Scott, 2014) covered by written rules and informal codes of conduct (North, 1990) and backed by some set of rewards and sanctions (Jepperson, 1991). The understanding of their role in the management literature has evolved from complete institutional blindness toward institutional determinism (Chizema, 2008).

Organizations exist and operate in an environment, which undergoes institutional changes resulting from the adoption of new laws, emergence of new standards or rules and the development of new practice and designs. The institutional change at the macro level requires a series of changes and adaptations at the micro (organizational) level (Aoki, 2007). The patterns of organizational response to the institutional change are extensively studied by the neo-institutional theory (DiMaggio and Powell, 1983; Meyer and Rowan, 1977; Mizruchi and Fein, 1999) explaining how elements of organizations, including structures, practices and professions, are created and diffused in society (Greve, 2003). The theory asserts that the institutional environment can strongly influence the development of those elements, often more profoundly than market pressures (Meyer, 1977). The reason for that is the fact that organizations are striving to attain legitimacy with their constituencies, which is believed to be crucial for organization survival as it provides access to resources from the environment (Deephouse, 1996; Mizruchi and Fein, 1999). This approach corresponds with the legitimacy proposal by Aprile ans Magnaghi (2012), who emphasize the 'social contract' between a company and the society. (Oliver, 1991) refers to the legitimacy motivation of organizational response to institutional change focused on social worthiness and resource mobilization.

It is not the competition or an objective requirement of efficiency but the organizations' pursuit of legitimacy, which pushes them to adopt practices and structures in line with socially prescribed dictates about what organization should do (Mizruchi and Fein, 1999). Organizations' response to institutional pressure and the experience of interactions with their peers lead to institutional isomorphism, which means that companies become similar following the same managerial practice (DiMaggio and Powell, 1983).

There are three mechanisms of isomorphic organizational change: coercive, mimetic and normative isomorphism. Coercive isomorphism constrained by the owners of firm resources results from formal and informal pressures of other organizations upon which the firm is dependent and of society's cultural expectations. Mimetic isomorphism is a result of uncertainty that encourages
INSTITUTIONAL ISOMORPHISM

Maria Roszkowska-Menkes Maria Aluchna 
INSTITUTIONAL ISOMORPHISM

Maria Roszkowska-Menkes Maria Aluchna organization to model themselves intentionally or unintentionally (through influence of consultants and employees hired from other companies) on more legitimate or successful peers. Finally, the normative isomorphism is stems from professionalization. It is driven by the similar education (graduate and postgraduate) of professionals and strengthened by their interactions within growing professional networks, across which new models diffuse rapidly. DiMaggio and Powell (1983) note that while the three types of isomorphic pressures often intermingle, they may lead to different outcomes, including, as we argue in the next section, adoption of different approaches to CSR.

\section{Isomorphic diffusion of CSR}

\subsection{The conceptual model}

The emergence of CSR is viewed as companies' reaction to social pressures and current business environment challenges including accelerating globalization and competition, climate change and the need for sustainable development, corruption, growing consumer and employee expectations (Rok, 2004). The adoption of CSR in the language of neo-institutional theory represents the case of the diffusion and institutionalization of change in formal organization structure (Greenwood et al., 2002) under the influence of four actors - law makers, market makers (providers of financial and production resources), model makers (consultants, market assessors, educators) and governance enactors (top managers, board members, controlling shareholders) - who carry normative, coercive and mimetic pressures (Enrione et al., 2006). Companies react to the institutional changes in different ways and, as we argue, depending on the type or particular mixture of types of isomorphic mechanisms affecting organizations different CSR approaches and strategies can be adopted. Table 2 proposes a conceptual framework referring CSR modes as identified by Visser (2012) with the CSR strategy and isomorphic pressures (DiMaggio and Powell, 1983; Mizruchi and Fein, 1999) enforced.

The proposed model starts with the lack of adoption of CSR activity, which may be viewed as the resistance to institutional change (Greenwood and Hinings, 1996) when the organization does not adjust its structures to new concepts and practices. Further, diffusion of defensive CSR is a result of coercive isomorphic pressures enforced mostly by law makers and organizational resource providers in order to minimize business irresponsibility. CSR is a strategy to avoid regulations (Mullerat, 2010) and costly repercussion, such as fines, lawsuits, consumer boycotts and decrease in sales (Husted and Salazar, 2006). Social and environmental programs are also harnessed in order to reduce political costs, such as taxes and fees and may also help company to obtain certain benefits from the government and justify their profits (Frias-Aceituno et al., 2014). While concentrating on shareholder value maximization, firm does the least that is required either by law 


\begin{tabular}{|c|c|c|}
\hline CSR mode & CSR strategy & $\begin{array}{l}\text { Isomorphism } \\
\text { mechanism }\end{array}$ \\
\hline $\begin{array}{l}\text { Corporate } \\
\text { irresponsibility }\end{array}$ & No CSR activity & None \\
\hline Defensive & $\begin{array}{l}\text { CSR adopted under the political and social pressure } \\
\text { aimed at maximization of shareholder value } \\
\text { Ad hoc CSR activities not related to core business } \\
\text { strategy } \\
\text { Cost avoidance }\end{array}$ & $\begin{array}{l}\text { Coercive } \\
\text { Legal }\end{array}$ \\
\hline Charitable & $\begin{array}{l}\text { CSR adopted under the social pressure aimed at } \\
\text { satisfying stakeholders expectations } \\
\text { CSR activity not related to core business strategy, limited } \\
\text { to community involvement and sponsorships } \\
\text { Altruistic giving back to the society }\end{array}$ & $\begin{array}{l}\text { Coercive Cultural/ } \\
\text { Normative }\end{array}$ \\
\hline Promotional & $\begin{array}{l}\text { CSR adopted under the social pressure aimed at } \\
\text { maximization of shareholder value } \\
\text { CSR activity not related to core business strategy, limited } \\
\text { to PR } \\
\text { Image building/ white- and greenwashing }\end{array}$ & $\begin{array}{l}\text { Coercive Cultural/ } \\
\text { Mimetic }\end{array}$ \\
\hline Strategic & $\begin{array}{l}\text { CSR adopted under uncertainty and market pressure } \\
\text { aiming at of maximization of shareholder value } \\
\text { CSR activity related to core business strategy based on } \\
\text { management systems and standards } \\
\text { CSR supports business strategy (win-win assumption) }\end{array}$ & $\begin{array}{l}\text { Mimetic/ } \\
\text { Normative }\end{array}$ \\
\hline Systemic & $\begin{array}{l}\text { CSR adopted under organizational culture pressures } \\
\text { aiming at maximization of shared value. } \\
\text { CSR activity integrated with core business strategy } \\
\text { Sustainable business models }\end{array}$ & Normative \\
\hline
\end{tabular}

INSTITUTIONAL ISOMORPHISM

Maria Roszkowska-Menkes Maria Aluchna

or by social expectations and its CSR activities are limited to ad hoc programs aimed at keeping the civil pressure down and often accompanied by company's hypocrisy (Fleming and Jones, 2013).

According to the proposed conceptual model presented in Table 2 charitable CSR is linked to coercive and normative isomorphism. In this case social activities are adopted under the cultural (rather than political) pressures of society expecting business to contribute to the society, but also as a result of deep conviction of decision makers in organizations (top managers and owners) that once you get rich you're obliged to be generous (Visser, 2012). Charitable CSR activities are not related to the core business strategy - they focus on "altruistic" giving back to the society or compensating negative impacts, but do not include any attempts to minimize those impacts. CSR is understood as a way in which the company redistributes value, rather than generates it, and as such is perceived as a cost or "as an 'add-on' luxury that can be only afforded by the most successful businesses" (Freeman and McVea, 2001)

Table 2. Isomorphic Diffusion of CSR Modes and Strategies 
INSTITUTIONAL ISOMORPHISM

Maria Roszkowska-Menkes Maria Aluchna
Fleming and Jones (2013) argue that what has come to be called corporate social responsibility has become a key marketing and branding tool for most large and medium-sized companies. In this promotional mode CSR is used as a PR or even green- and whitewashing tool (Faust, 2006). CSR programs, rarely related to the core business strategy, are usually created by marketing or PR units, and are limited to cosmetic actions, the centrepiece of which are often glossy CSR reports (Porter and Kramer, 2006). Still the main objective, as Professor Yunus (2007) argues, is to generate as much profit as possible no matter what impact it might have on society and environment. If the impact turns out to be negative, then managers decide to donate some portion of the profits for social causes, making sure that their generosity attracts appropriate media attention. As argued by Meyer and Rowan (1977) in their study on organization myth and ceremony, companies, for the purpose of attaining legitimacy within their environments, construct stories about their actions that correspond social expectations. Diffusion of promotional CSR stems from coercive (mostly cultural) isomorphic pressures linked to the rapid growth of ethical consumerism (Doane, 2001). It is, however, additionally enforced by mimetic isomorphism. CSR activities of global leaders, as well as success stories of ethical and eco brands, such as TOMS, VEJA or Patagonia, foster a fashion for sustainability and encourage companies to heavily promote their social and environmental image.

Some authors (Scott, 1987; Tolbert and Zucker, 1983) argue that coercive institutional power foster rather superficial changes in the organizational structures and practices, encouraging only formal introduction of changes that are loosely coupled to actual (informal) business activities (Meyer and Rowan, 1977). Therefore, we argue that coercive isomorphic mechanism drive diffusion of the three first, non-strategic CSR modes.

Strategic CSR refers to instrumental premises of stakeholder theory (Donaldson, 1995). Freeman (1999) argues that in turbulent environment "to maximize shareholder value over an uncertain time frame, managers ought to pay attention to key stakeholder relationships". Stakeholder management and CSR are proposed as an alternative (to shareholder model) approach to strategic management that would help managers to understand new opportunities, identify risks, and make strategic decisions how to exploit the first and minimize the latter. Business success is believed to be determined by the alignment of interests of key stakeholders with the company's core strategy (Freeman and McVea, 2001). This approach, in the contrary to the previous modes, goes beyond cost-perspective and profit redistribution towards building business case for CSR (Visser, 2012). Firm voluntarily invests in social and environmental initiatives, but designs them in a way that supports realization of the core business strategy (Husted, 2006; Lantos, 2002). This approach is based on the win-win assumption about businesssociety relations, neglecting potential conflict of interests. 
We argue that strategic mode is diffused through mimetic and normative isomorphism mechanisms. Under the conditions of uncertainty, which is increased by growing expectations and power of different stakeholder groups, as well as accelerating globalization processes and resource scarcity, companies imitate structures and practices that have proven to be successful in other organizations (Mizruchi and Fein, 1999). Indeed, it has been observed that while adopting sustainability practices, many companies desire to make sure either that they did not fall behind the competition on CSR grounds or to take a leadership role around CSR initiatives (Bondy, 2009). Another source of mimetic isomorphism is the growth of CSR consulting industry promoting CSR standards, codes of best practice and management systems. Diffusion of strategic approach to sustainability is additionally reinforced by professionalization of managers in this area. In response to the growing awareness on the role of business in society and the criticism of the neoliberal doctrine dominance, institutions of higher education have expanded sustainability in their curricula (Sherif, 2015). Business ethics, sustainability, corporate social responsibility - in general business in society courses are available for students not only in majority of business schools, but also increasingly at engineering universities (Hernandez et al., 2007).

Finally, in the systemic mode of CSR company integrates its core business strategy and customer value proposition with social and environmental issues (Becker-Olsen, 2014). Business and social goals are tied up with each other and CSR becomes a defining element for company's business model (Boons and Lüdeke-Freund, 2013) that aims at shared value creation (Porter and Kramer, 2006). Systemic or integrative approach to CSR is diffused from within organizations through normative isomorphism mechanism - the process that corresponds with (Selznik, 1957) value infusion. Creation of ethical and sustainable organizational cultures is driven by values of managers and owners, who believe that the engagement in social and environmental activity and taking responsibility by the company for its overall impact is simply the right thing to do. CSR and sustainability are "taken-for-granted" and set the most obvious and natural way to conduct business operations (Berger and Luckmann, 1967).

\subsection{Directions for further research}

The proposed conceptual model integrates two approaches - CSR modes and institutional theory. This integration offers a new perspective on understanding why and how companies adopt CSR. The existing literature suggests that the motivations driving the CSR adoption may be very different. At the same time the transition towards CSR may be viewed as an institutional change embedded in growing social awareness and environmental limitations and supported by stakeholders pressure and regulation. In result the adoption of CSR may be driven by the isomorphic changes undertaken by companies either to improve market
INSTITUTIONAL ISOMORPHISM

Maria Roszkowska-Menkes Maria Aluchna 
INSTITUTIONAL ISOMORPHISM

Maria Roszkowska-Menkes Maria Aluchna position and enable competition with rival companies or to satisfy stakeholders and regulators. As the adoption of CSR represents a significant change in the organizational behavior it can be driven by a number of factors and motivations simultaneously.

The integration of CSR modes (Visser, 2012) and institutional theory (DiMaggio and Powell, 1983; Mizruchi and Fein, 1999) provides a set of opportunities for further research. These directions include:

- The exemplification of mimetic, coercive and normative isomorphism mechanism affecting process of organizational reaction to institutional change of growing importance of CSR and sustainability;

- The identification of links between mimetic, coercive and normative isomorphic mechanisms and organizational context (size, sector of operation, ownership structure, financial performance, market position, strategy, internationalization);

- The identification of links between mimetic, coercive and normative isomorphic mechanisms and institutional context (regulatory regime, market coordination, development stage).

\subsection{Practical implications}

The proposed model by identifying different diffusion patterns of CSR modes offers practical implications for policy development in the area of promoting CSR practices among companies. There is increasing regulatory interest in corporate social responsibility and sustainability worldwide. For example India introduced a change in company law mandating businesses with annual revenues of more than $10 \mathrm{bn}$ rupees (143m euro) to give away $2 \%$ of their net profit to charity (Chhabra, 2014). South Africa became the first jurisdiction to mandate integrated form of disclosure in 2010. The driver for this was the King Code of Governance Principles for South Africa 2009 (King III) becoming a requirement for entities listed on the Johannesburg Securities Exchange. King III recommends that organizations should adopt integrated reporting on an 'apply or explain' basis. New mandatory reporting rules in Europe (Directive 2014/95/EU) and stock exchange listing rules in, inter alia, Singapore, Kuala Lumpur and Copenhagen also require companies to disclose non-financial information (still not necessarily integrated with financial information). However some authors (Brown and Dillard, 2014) suggest that overcoming shortcomings of the dominating neoliberal doctrine is not just the matter of introduction of mandatory regulations. As it has been argued in the proposed model coercive pressures have little impact on the diffusion of strategic or systemic modes of CSR. Thus policies and frameworks focused on promotion of the two latter should be base rather on the education system, professional networking and authority power. 


\section{Conclusion}

The existing literature on CSR and sustainability offers a wide range of studies encored in a number of conceptual and theoretical approaches. The emergence of different definitions and research lenses requires structuring the research contribution and available findings. This could be offered with the support of results of other organizational studies.

This paper proposes the conceptual framework for understanding organizational response to institutional changes represented by the growing importance of CSR and sustainability. The paper is of theoretical character and using the contribution of CSR concept integrated with the neo-institutional theory it models companies' approaches for adopting CSR through the lens of three isomorphic efforts. The development and formalization of CSR in regulations and stakeholder expectations can be viewed as an example of institutional change. In particular, assuming that organizations need to adopt to this change the paper links CSR modes - defensive, charitable, promotional, strategic, systemic - with mimetic, coercive and normative isomorphism mechanisms. Finally, using the framework of proposed conceptual model the paper provides a set of opportunities for further research and implications for policy.

\section{References}

Aoki, M. (2007), "Endogenizing Institutions and Institutional Changes", Journal of Institutional Economics, Vol. 3 No. 1, pp. 1-39. DOI: 10.1017/S1744137406000531

Aprile, R., Magnaghi, E. (2012), "Integrated reporting: a theoretical perspective on this critical issue", paper presented at The $8^{\text {th }}$ Interdisciplinary Workshop on "Intangibles, Intellectual Capital \& Extra-Financial Information”, 27-28 September 2012, Grenoble, France.

Becker-Olsen, K.L. (2014), “The CSR Conundrum: Understanding Consumer Response to Corporate Social Responsibility", in: Hill, R.L., Langan, R. (Eds.), Handbook of Research on Marketing and Corporate Social Responsibility, Edward Elgar Publishing, Cheltenham, pp. 149-174.

Berger, P. L., Luckmann, T. (1967), The Social Construction of Reality, New York: Doubleday, New York.

Bondy, K. (2009), "Isomorphism in the Practice of Corporate Social Responsibility: Evidence of an Institution and its Decline", University of Bath School of Management Working Paper Series, No. 10, pp. 1-43.

Boons, F.M., Lüdeke-Freund, F. (2013), "Business Models for Sustainable Innovation: State-of-the art and Steps Towards a Research Agenda", Journal of Cleaner Production, Vol. 45, pp. 9-19.

Brown, J., Dillard, J. (2014), "Integrated Reporting: On the Need for Broadening Out and Opening Up", Accounting, Auditing \& Accountability Journal, Vol. 27 No. 7, pp. 1120-1156. DOI: 10.1108/AAAJ-04-2013-313

Carroll, A.B. (1979), "Three-Dimensional Conceptual Model of Corporate Performance", The Academy of Management Review, Vol. 4 No. 4, pp. 497-505.
INSTITUTIONAL ISOMORPHISM

Maria Roszkowska-Menkes Maria Aluchna 
INSTITUTIONAL ISOMORPHISM

Maria Roszkowska-Menkes Maria Aluchna
Charan, R., Freeman, R.E. (1980), "Planning for the Business Environment of the 1980s", Journal of Business Strategy, Vol. 1 No. 2, pp. 9-19. DOI: 10.1108/eb038895

Chhabra, E. (2014), "Corporate Social Responsibility: Should It Be A Law?", Forbes, available at: https://www.forbes.com/sites/eshachhabra/2014/04/18/corporate-socialresponsibility-should-it-be-a-law/\#d282d9137363 (accessed 5 June 2017).

Chizema, A. (2008), "Institutions and Voluntary Compliance: The Disclosure of Individual Executive Pay in Germany", Corporate Governance: An International Review, Vol. 16 No. 4, pp. 359-374. DOI: 10.1111/j.1467-8683.2008.00689.x

COM (2011) 681: Communication from the Commission to the European Parliament, the Council, the European Economic and Social Committee and the Committee of the Regions: A renewed EU strategy 2011-14 for Corporate Social Responsibility, Brussels.

Dahlsrud, A. (2008), "How Corporate Social Responsibility is Defined: an Analysis of 37 Definitions", Corporate Social Resposibility and Environmental Management, Vol. 15, pp. 1-13. DOI: 10.1002/csr.132

Deephouse, D.L. (1996), “Does Isomorphism Legitimate?", Academy of Management Journal, Vol. 39 No. 4, pp. 1024-1039. DOI: 10.2307/256722

DiMaggio, P.J., Powell, W.W. (1983), “The Iron Cage Revisited: Institutional Isomorphism and Collective Rationality in Organizational Fields", American Sociological Review, Vol. 48 No. 2, p. 147. DOI: 10.2307/2095101

Doane, D. (2001), "Taking Flight: The rapid Growth of Ethical Consumerism. New Economics Foundation", available at: http://b.3cdn.net/nefoundation/dcca99d75656 2385f9_xtm6i6233.pdf (accessed 5 June 2017).

Donaldson, T. (1982), Corporations and Morality, New York: Prentice-Hall, New York.

Donaldson, T., Preston, L. (1995), "The Stakeholder Theory of the Corporation: Concepts, Evidence, and Implications", The Academy of Management Review, Vol. 20 No. 1, pp. 65-91.

Enrione, A., Mazza, C., Zerboni, F. (2006), "Institutionalizing Codes of Governance", American Behavioral Scientist, Vol. 49 No. 7, pp. 961-973. DOI: 10.1177/000276420 5285175

Faust, C. (2006), What's Wrong with Corporate Social Responsibility?, Corporate Watch Report, Oxford.

Fleming, P., Jones, M.T. (2013), The End of Corporate Social Responsibility. Crisis and Critique, Sage Publications.

Freeman, R.E. (1999), "Divergent Stakeholder Theory”, The Academy of Management Review, Vol. 24 No. 2, pp. 233-236.

Freeman, R.E., McVea, J. (2001), "A Stakeholder Approach to Strategic Management", SSRN Electronic Journal, January. DOI: 10.2139/ssrn.263511

Freeman, R.E., Reed, D.L. (1983), "Stockholders and Stakeholders: A New Perspective on Corporate Governance", California Management Review, Vol. 25 No. 3, pp. 88-106.

Frias-Aceituno, J.V., Rodríguez-Ariza, L., Garcia-Sánchez, I.M. (2014), "Explanatory Factors of Integrated Sustainability and Financial Reporting", Business Strategy and the Environment, Vol. 23 No. 1, pp. 56-72. DOI: 10.1002/bse.1765 
Territory", Journal of Business Ethics, Vol. 53 No. 1/2, pp. 51-71. DOI: 10.1023/B:B USI.0000039399.90587.34

Greenwood, R., Hinings, C.R. (1996), “Understanding Radical Organizational Change: Bringing together the Old and the New Institutionalism", The Academy of Management Review, Vol. 21 No. 4, pp. 1022-1054. DOI: 10.2307/259163

Greenwood, R., Hinings, C.R., Suddaby, R. (2002), “Theorizing Change: The Role of Professional Associations in the Transformation of Institutionalized Fields", Academy of Management Journal, Vol. 45 No. 1, pp. 58-80. DOI: 10.2307/3069285

Greif, A. (2006), Institutions and the Path to the Modern Economy, Cambridge University Press, Cambridge.

Greve, H.R. (2003), Organizational Learning from Performance Feedback: A Behavioral Perspective on Innovation and Change, Cambridge University Press, Cambridge.

Hernandez, J., Mendibil, K., Ion, B. (2007), "Coporate Social Responsibility as a Fundamental Discipline: Our Reposnse to Mainstream IT in SMEs", in: Bohemia, E., Hilton, K., McMahon, C., Clarke, A. (Eds.), Proceedings of $9^{\text {th }}$ International Conference on Engineering and Product Design Education, Northumbria University, Newcastle Upon Tyne, United Kingdom, pp. 21-26.

Husted, B.W., Salazar, J. (2006), "Taking Friedman Seriously: Maximizing Profits and Social Performance”, Journal of Management Studies, Vol. 43 No. 1, pp. 75-91. DOI: 10.1111/j.1467-6486.2006.00583.x

Jepperson, R.L. (1991), “Institutions, Institutional Effects, and Institutionalism”, in: Powell W.W., DiMaggio, P.J. (Eds.), The New Institutionalism in Organizational Analysis, University of Chicago, Chicago, pp. 143-163.

Lantos, G.P. (2002), "The Ethicality of Altruistic Corporate Social Responsibility", Journal of Consumer Marketing, Vol. 19 No. 3, pp. 205-232. DOI: 10.1108/073 63760210426049

Marrewijk, M. (2003), "Concepts and Definitions of CSR and Corporate Sustainability: Between Agency and Communion”, Journal of Business Ethics, Vol. 44 No. 2-3, pp. 95-105. DOI: 10.1023/A:1023331212247

Martin, R. (2002), “The Virtue Matrix: Calculating the Return on Corporate Responsibility", Harvard Business Review, Vol. 80 No. 3, pp. 68-75.

McWilliams, A., Siegel, D.S., Wright, P.M. (2006), "Corporate Social Responsibility: Strategic Implications", Journal of Management Studies, Vol 43 No. 1, pp. 1-18. DOI: 10.1111/j.1467-6486.2006.00580.x

Meyer, J.W., Rowan, B. (1977), "Institutionalized Organizations: Formal Structure as Myth and Ceremony on JSTOR", American Journal of Sociology, Vol. 83 No. 2, pp. 340-363.

Mizruchi, M.S., Fein, L.C. (1999), "The Social Construction of Organizational Knowledge: A Study of the Uses of Coercive, Mimetic, and Normative Isomorphism", Administrative Science Quarterly, Vol. 44 No. 4, pp. 653-683. DOI: 10.2307/2667051

Mullerat, R. (2010), International Corporate Social Responsibility: The Role of Corporations in the Economic Order of the $21^{\text {st }}$ Century, Kluwer Law International, Alphen aan den Rijn.

North, D. (1990). Institutions, Institutional Change and Economic Performance, Cambridge University Press, Cambridge.
INSTITUTIONAL ISOMORPHISM

Maria Roszkowska-Menkes Maria Aluchna 
INSTITUTIONAL ISOMORPHISM

Maria Roszkowska-Menkes Maria Aluchna
Oliver, C. (1991), "Strategic Responses to Institutional Processes", The Academy of Management Review, Vol. 16 No. 1, pp. 145-179. DOI: 10.2307/258610

Porter, M.E., Kramer, M.R. (2002), "The Competitive Advantage of Corporate Philanthropy". Harvard Business Review, December, pp. 56-69.

Porter, M.E., Kramer, M.R. (2006), "Strategy and Society: The Link Between Competitive Advantage and Corporate Social Responsibility", Harvard Business Review, December, pp. 78-92.

Porter, M.E., Kramer, M.R. (2011), "Creating Shared Value”, Harvard Business Review, January-February, pp. 62-77.

Rok, B. (2004), Odpowiedzialny biznes w nieodpowiedzialnym świecie, Akademia Rozwoju Filantropii, Forum Odpowiedzialnego Biznesu, Warszawa.

Scott, R.W. (2014), Institutions and Organizations. Ideas, Interests, Identities, Sage Publications, London.

Scott, W.R. (1987), "The Adolescence of Institutional Theory", Administrative Science Quarterly, Vol. 32 No. 4, pp. 493-511. DOI: 10.2307/2392880

Selznik, P. (1957), Leadership in Administration, Harper \& Row, New York.

Sethi, R. (1975), "Dimensions of Corporate Social Performance: An Analytical Framework", California Management Review, Vol. 17 No. 3, pp. 58-64.

Sherif, S.F. (2015), "The Role of Higher Education Institutions in Propagating Corporate Social Responsibility Case Study: Universities in the Middle East", International Journal of Education and Research, Vol. 3 No. 1, pp. 217-226.

Tolbert, P., Zucker, L. (1983), "Institutional Sources of Change in the Formal Structure of Organizations: The Diffusion of Civil Service Reform, 1880-1935”, available at: http://digitalcommons.ilr.cornell.edu/cgi/viewcontent.cgi?article=1132\&context=art icles (accessed 15 September 2017).

Visser, W. (2012), The Age of Responsibility: CSR 2.0 and the New DNA of Business, Willey, London.

Wartick, S.L., Cochran, P.L. (1985), “The Evolution of the Corporate Social Performance Model", The Academy of Management Review, Vol. 10 No. 4, pp. 758-769.

Wood, D.J. (1991), "Corporate Social Performance Revisited”, The Academy of Management Review, Vol. 16 No. 4, pp. 691-718.

Yunus, M. (2007), Creating a World Without Poverty: Social Business and the Future of Capitalism, PublicAffairs, New York. 